\title{
RIDING OUT THE STORM: OUT-OF-FIELD TEACHING PRACTICE IN INDONESIA
}

\author{
Esti Rahayu'; Shuki Osman² \\ ${ }^{1}$ Language Center, Faculty of Humanities, Bina Nusantara University \\ Jl. Kemanggisan Illir III No. 45, Palmerah, Jakarta 11480, Indonesia \\ ${ }^{2}$ School of Educational Studies, Universiti Sains Malaysia \\ Jl. Sungai Dua, 11700 Universiti Sains Malaysia, Penang, Malaysia \\ 'estirahayu@gmail.com; 2shuki@usm.my
}

Received: $14^{\text {th }}$ May 2019/Revised: 02 $2^{\text {nd }}$ July 2019/ Accepted: $10^{\text {th }}$ July 2019

How to Cite: Rahayu, E., \& Osman, S. (2019). Riding out the storm: Out-of-field teaching practice in Indonesia.

Humaniora, 10(2), 161-166. https://doi.org/10.21512/humaniora.v10i2.5628

\begin{abstract}
As out-of-field teachers existence led to change in teachers, the research aimed to explore their commitment to learning and teaching, and how their schools supported them. Five Indonesian teachers who started teaching as out-of-field teachers and their school leaders were interviewed for data collection. The qualitative case study was employed to explore the problem through interviews, classroom observations, and document analysis. The findings reveal that the initial commitment to teaching, learning, and growing is an investment for further actions throughout the teaching practice. The schools provide necessary assistance through the induction and during their in-service in the provided and requested professional learning, being trusted and acknowledged by school leaders, and having resourceful colleagues. From their schools'support, the outof-field teachers become more knowledgeable and remain as teachers for an extended time.
\end{abstract}

Keywords: out-of-field teachers, teacher commitment, professional learning

\section{INTRODUCTION}

Out-of-field teachers do not possess teaching qualifications or are qualified, but they teach a year level, subject, or field beyond their expertise. Out-of-field teaching practice is a common issue in countries such as the US, Australia, South Korea, and Germany (Hobbs, 2012; Ingersoll, 2006; 2005; Kim, 2011; Robinson, 1985; Sharplin, 2014; Törner \& Törner, 2012) because available research in those countries pertains to out-of-field teaching practice.

In the mid-1980s, concerns about out-of-field teaching emerged in the US when a report examined the extent of out-of-field teacher assignments in 50 states (Robinson, 1985). Between 1998 and 2006, Ingersoll (2006); Ingersoll (2005) investigates how prevalent out-offield teaching has become by focusing on the complexity of the phenomenon. The results show that out-of-field teaching exists as an organizational issue. It happens in all types of schools and all areas geographically.

In Australia, several researchers examine the out-offield teaching phenomenon. Hobbs (2012) has explored the factors influencing out-of-field teaching. It includes context, support mechanisms, and personal resources. Moreover,
Sharplin (2014) has found that teacher shortages lead to out-of-field teachers in rural areas and hard-to-staff schools. Based on the findings, there are six distinct categories of out-of-field teachers to use for further examination of the practice. Then, Kim (2011) has found that a higher number of public school teachers in South Korea are assigned to teach out-of-field subjects compared to teachers in private schools. In Germany, out-of-field teaching practice occurs at the principal's discretion. It is to cover their school's needs as there is a lack of teachers (Törner \& Törner, 2012).

Out-of-field teachers are not at a qualified teacher's level of education because they usually possess a bachelor's degree (Du Plessis, 2017; Ingersoll, 2005). Out-of-field teaching occurs when there is a discrepancy between a teacher's placement and their field of expertise (Du Plessis, 2017). Teachers become out-of-field when their school leaders assign them to fill vacant positions. School leaders assume that teachers can use their experience in primary and secondary schools to teach. In practice, they face mixed feelings of confusion and anxiety regarding their competency. These feelings affect the school community and the relationship between teachers and students (Du Plessis, 2013). Paired with a low commitment to teaching, misplacement leads to high attrition rates (DarlingHammond et al., 1999). 
In addition, because of the mentioned discrepancy, out-of-field teachers struggle with pedagogical content knowledge (Du Plessis, Carroll, \& Gillies, 2015). They are not trained teachers. This condition affects their teaching strategies and disturbs their lesson effectiveness (DarlingHammond, 2010).

Out-of-field teaching is present in Indonesia despite a few statistics to demonstrate this. Jakaria (2014) provides the only available literature regarding Indonesia's outof-field teachers. The research is written in Indonesian and discusses the number of out-of-field primary school teachers between 2010 and 2013. The result shows that approximately $67 \%$ of primary school teachers in Indonesia are not qualified. Most of them do not hold bachelor degrees, especially in remote provinces. However, this research does not provide any voices from out-of-field teachers. Instead, it presents quantitative data presentation and discussion related to the regulations.

Despite the research suggesting that a school management's misplacement is the reason for teachers adopting an out-of-field practice, Hobbs (2013) has revealed that teachers become out-of-field to pursue their teaching interests. The research suggests that teachers face a new challenge and embrace the opportunity to extend their identities and knowledge. Teachers thrive in their profession and acquire new knowledge. The teachers remain because they are supported in a working environment that provides collaboration among staff. Similarly, Du Plessis (2017) has argued that out-of-field teachers develop their knowledge and skills of teaching out-of-field when it is connected closely to their interest and passion. Teachers require adequate time for further learning, development, and collaboration with qualified colleagues for mentoring. This research explores an out-of-field teacher's practices in Indonesia, focusing on their commitment to teaching and learning in their school and their professional growth. It also explores the support provided by out-of-field teachers' schools.

This research relates to teachers mentioned by Hobbs (2013) regarding those who choose to work outof-field to pursue their interest in teaching. The teachers in this research have been teaching in Satuan Pendidikan Kerjasama (SPK) for over 12 years and are currently still teaching. Their length of service shows their commitment to teaching, learning, and growth. Throughout their service, their commitment is in accordance with school support.

Commitment is a high level of attachment to someone or something in a social endeavor (Tyree Jr, 1996). Tyree Jr (1996) has further explained that teacher commitment is linked to their school support, involvement with school activities, and loyalty to remain at the school. Commitment is also considered as enthusiasm, belief in an ideal (vision), hard work, a sense of social justice, an awareness of the need to attend to their continuing development, and a recognition of priorities (Day, Elliot, \& Kington, 2005). For this research, teachers' commitment refers to a teacher's enthusiasm and responsibility to learn, teach, and grow.

Commitment can change over time (Day, Elliot, \& Kington, 2005). Uncontrollable changes along the teaching journey prompt out-of-field teachers to adjust their commitments. Factors such as personal life, school context, teaching, professional development (PD) can either strengthen or weaken their commitment. Personal life factors include a teacher's positive motivation toward their growth and support from people external to the school (Fransson \& Frelin, 2016). School context includes support from within the school, such as the acknowledgment from school leaders (Day \& Gu, 2007). Tsui and Cheng (1999); Van Veen, Sleegers, and Van de Ven (2005) have observed that teachers are committed to schools with a collaborative working culture and who support their growth. Teaching refers to teachers' daily work, and professional development relates to teachers undertaking professional learning. Despite the commitment relating to the individual, it is facilitated by those factors. When it is changed, they may affect the teachers and challenge their commitment.

Commitment is a critical predictor of teachers' work performance (Day, Elliot, \& Kington, 2005). Highly committed teachers perform admirably, but teachers lacking commitment can create absenteeism, resignation, or leaving the profession altogether. Teachers with a low commitment can be determined from their initial statement to teaching in their beginning years by saying that they will look at what teaching can bring them in the future (Huberman, 1989).

Because the out-of-field teachers are not trained teachers, school support is crucial to their professional development. School learning is inevitable. The school support consists of school leaders and colleagues who support professional growth and a learning environment. Out-of-field teachers participate in activities that indicate their thinking, acting, and learning activities and practices (Billett, 2004; Fuller \& Unwin, 2004). In the learning environment, out-of-field teachers acquire skills and knowledge from participating in activities and online courses. These are supported and guided (directly or indirectly) by highly experienced mentors who have the intention of developing the teachers' knowledge and skill (Billett, 1993; Lampert \& Ball, 1999). Therefore, ongoing, cumulative, and transformative school support is in the form of moment-by-moment learning (Scribner, 1985).

To provide continuous learning for out-of-field teachers, school leaders should provide teacher activities that generate expertise through everyday practice. Teachers' learning at school is not just physical action. It is the product of everyday thinking and acting through asking questions, receiving information, locating resources and people, listening and observing activities, learning from mistakes, and reflecting (Eraut, 2014). Senior colleagues are a credible source of knowledge and should provide direct guidance for the out-of-field teachers. Moreover, other colleagues should provide indirect guidance through answering questions, listening to the best practice based on colleagues' experience, observing other classes and being observed, and receiving feedback (Billett, 2003).

The teachers examined in this research have taught for over ten years and possess an initial commitment that may arise, be sustained, or decline depending on their life and work experiences (Day, 2008). Their initial commitment becomes their investment in their teaching career (JarvisSelinger, Pratt, \& Collins, 2010).

From the mentioned explanation, it shows that outof-field teaching is a complex phenomenon. Out-of-field teaching practice is a common issue in several countries including Indonesia. It presents itself as an easy solution to teacher shortages for school. However, it introduces a challenge that leads to career change and professional identity expansion for out-of-field teachers. This research aims to be one part of that complex phenomenon that has not been explored before, especially in the Indonesian context. It also aims to explore the teachers' commitment to learning and teaching, and how their schools support them. 


\section{METHODS}

Qualitative research is suitable for this research because it allows for descriptions of the out-of-field teachers. Creswell and Creswell (2017) have defined a case study as an exploration of a bounded system. It is case or cases over time using multiple sources. The detailed description provides a deeper understanding of an out-of-field teacher's commitment related to their learning and teaching in school. It also provides a deeper understanding of school support to the out-of-field teachers.

This research is carried out in Jakarta, Bandung, and Tangerang. It is done between April and July 2018 at SPK (formerly known as International School). Indonesian students attend SPK, and the teachers are both local (having Indonesian nationality) and expatriates. SPK uses overseas curricula, including Cambridge, IB, and Abeka. However, it also teaches mandatory subjects in Indonesian such as Indonesian Language, Civics, and Religion. The medium of communication for every other subject is English.

There are ten participants of this research. Five teachers are purposefully selected. They are Indonesian teachers who have been teaching in SPK for more than 12 years. Meanwhile, the other five are school leaders. A teacher's commitment to the teaching profession is one of the centers in this research. School leaders are interviewed to complement teachers' interviews by obtaining information about their decision to hire out-of-field teachers and their support for the teachers. Semi-structured audiotaped interviews with school leaders and out-of-field teachers, classroom observations, and teachers' documents provide data for this research. Table 1 shows the description of these ten teachers.

Table 1 Participants of This Research

\begin{tabular}{cl}
\hline Code & \multicolumn{1}{c}{ Description } \\
\hline T1 & $\begin{array}{l}\text { Preschool teacher, female, 14 years of teaching, } \\
\text { Bachelor of Communication }\end{array}$ \\
T2 & $\begin{array}{l}\text { Elementary school teacher, female, 13 years of } \\
\text { teaching, Bachelor of Accountancy }\end{array}$ \\
T3 & $\begin{array}{l}\text { Junior high school teacher (teaching English), } \\
\text { male, 13 years of teaching, Bachelor of }\end{array}$ \\
Engineering & $\begin{array}{l}\text { Senior high school teacher (teaching chemistry), } \\
\text { female, 14 years of teaching, Bachelor of }\end{array}$ \\
Mathematics and Science & $\begin{array}{l}\text { Technology integrator for preschool to senior } \\
\text { high school, 14 years of teaching, Bachelor of } \\
\text { Arts (English Literature) }\end{array}$ \\
L1 & $\begin{array}{l}\text { SPK principal, director, and school owner } \\
\text { (Cambridge curriculum), male }\end{array}$ \\
L2 & $\begin{array}{l}\text { SPK principal, director, and school owner (IB } \\
\text { curriculum), female }\end{array}$ \\
L3 & $\begin{array}{l}\text { SPK director (former principal), female } \\
\text { SPK principal, male }\end{array}$ \\
L4 & SPK principal, female
\end{tabular}

Data analysis consists of six sequential stages of thematic analysis following the procedures developed by Braun and Clarke (2006). This method is chosen for its flexibility. It includes a recursive process in which the researcher can switch between stages of analysis if necessary. To demonstrate the research's authenticity and for the reader to ascertain the efficacy of methods, data collection procedures, and the interpretation process are thorough. Utilizing member checking ensures accuracy of data collection and interpretation.

\section{RESULTS AND DISCUSSIONS}

From the analysis, three major themes emerge for discussion. Those are out-of-field teachers' initial commitments, administrative support and collegial aid, and remaining in the teaching profession for more than ten years. Each theme will be elaborated.

The first theme is out-of-field teachers' initial commitments. Based on the interviews, each out-of-field teachers are already interested in teaching. They do not go to college to study teaching, but they teach English, Mathematics, or Science in tuitions in their hometown when they are college students. The opportunity to become teachers come when International School (renamed SPK) is opened in Indonesia. To apply as a teacher, the school leader's requirements are holding a bachelor degree (any major), being proficient in English, and having an interest in teaching. Teaching experience can be presented, but it is not mandatory. School leaders quickly realize that finding experienced Indonesian teachers who can teach in English is difficult. The school leaders believe that potential candidates can learn to teach through practice.

L1 shares that the interviews are conducted in English, so the applicants must be able to speak and explain their thoughts in English (first interview, April 14, 2018). L2 adds that the applicants with good English competency but lack of pedagogy can be developed more easily than applicants with qualifications but lack of English competency (first interview, April 28, 2018). L5 shares that getting Indonesian teachers who can confidently speak English is not easy. Those who apply are overseas graduates, local graduates from English departments or non-English departments (graduates who have high English proficiency (first interview, April 21, 2018).

$\mathrm{T} 1$ states that she has loved teaching since teaching in daycare during her college day. It is so rewarding (first interview, April 28, 2018). T2 also admits that she is used to helping her nieces and nephews to do their homework. It is fun (first interview, April 14, 2018). T3 explains that returning from the States, his English sounds very American. His friend drags him to the tuition where he works for teaching English (first interview, May 12, 2018).

Similarly, T4 has stated that she is used to welcoming the kids in her village to do their homework in her house (first interview, May 27, 2018). Then, T5 says, "I have always wanted to be a teacher, but I am not accepted in English education" (first interview, June 2, 2018). These statements demonstrate an investment in their teaching career (Jarvis-Selinger, Pratt, \& Collins, 2010).

Next, the applicants are asked to demonstrate their teaching. L4 says, "You can see the 'fire' when they are teaching. If I am affected by her 'fire', my students will be affected too" (first interview, May 27, 2018). The first meeting with the school leaders reflects on the out-of-field teacher's initial commitment to teaching and motivation to learn and grow. When the leaders feel that the candidates can develop their skills in the future, they are hired.

The teachers in this research are aligned with 
the out-of-field teaching characteristics, as discussed by Ingersoll (2005). They all hold a bachelor degree, however, these teachers pursue an interest (Hobbs, 2012) in teaching instead of being misplaced by the school leaders. According to Hobbs (2012), this type of teachers is more committed learners. Since they have high commitment to learning, teaching, and growing, they remain to teach for more than ten years. This evidence settles the argument of Day, Elliot, and Kington (2005) that commitment is one of the predictors of teachers' attrition.

The second theme is related to administrative support and collegial aid. Every school leader admits that the accepted candidates lack basic knowledge for teaching. It includes knowledge of the subject, teaching methods, classroom management strategies, and knowledge of how to teach specific content to learners in different contexts. Despite this, the teachers are committed to teach and have the motivation to learn. Thus, school leaders create a development plan. They allocate a budget portion for professional learning and development for those teachers to be used before they begin teaching or while they are in service.

L1 states that one of the benefits they offer to the candidates during the interview is their professional development (first interview, April 14, 2018). Similarly, L2 agrees that she always believes they can retain the teachers by fulfilling what they need in their daily teaching (first interview, April 28, 2018).

Over several days, the participants' schools provide teacher inductions. It is followed by a two-day annual conference for new and existing teachers. L3's school provides each teacher with different books at the beginning of the academic year. The books' content and teachers' reflection become the materials for a sharing session in their monthly meeting.

Teachers are also scheduled to observe experienced teachers' classes before and during the service. Schools can also have a mentoring system, in which mentees visit their mentor's class several times in a term. All schools assign in-field or experienced teachers as subject coordinators that they help out-of-field teachers prepare classes with materials and teaching methodology. The out-of-field teachers are also assigned to webinars. Few schools provide scholarships for their teachers to complete a master degree. In these cases, three teachers accept the scholarship from their respective schools. Two of them pay for their study while their school provides fewer responsibilities during their study.

In-service learning is also completed in the respective departments in each school. Everyday interactions in the staff room with the head of department and colleagues indirectly shape the out-of-field teachers to improve their daily teaching. T3 says he asked for suggestions from his senior teachers. After listening to all suggestions and their discussions, he chooses one or two that suits his students. If the first one does not work, he tries the second one, all trial, and errors (first interview, May 12, 2018). T1 states that they are given choices once a year for the online training from Australia (first interview, April 28, 2018). T2 says that they can request PD that they need, but the school does not provide it (first interview, April 14, 2018).

There is also an annual conference for all SPK teachers hosted by SPK in Indonesia. The conference not only presents keynote speakers but also allows experienced senior teachers to share their best practices. The conference also allows teachers to connect with those from other schools.
School including management, leaders (principal and director), and colleagues are the main support for teachers' growth. Based on the findings, the schools provide positive experiences to the teachers. The school assists newly hired out-of-field teachers to adjust to their new environment. This includes professional learning plan that is spread throughout the academic year. Another finding is related to colleagues who allot time for discussion and permit them to observe. The interactions in teachers' room help them to form to be more effective teachers. These adequately support working conditions and make the teachers stay (Hobbs, 2013).

The results are in line with Tsui and Cheng (1999); and Van Veen, Sleegers, and Van de Ven (2005). The school with a collaborative culture and sufficient support for the teacher influence teachers' commitment to stay in the profession. The findings also indicate that schools support the teachers in developing their professional identity. The adequate support and resourceful working conditions of SPK schools evidently encourage the teachers to remain in their profession.

The last theme is their commitment to remain in the teaching profession for more than ten years. All teachers express that their school is one of the reasons they remain as a teacher. T1 discusses the administrative staff. This school has a good management team. They acknowledge the teacher's level of commitment. The teachers understand that they work hard, and they support the teachers by giving them time and space to attend training (first interview, April 28, 2018).

Similarly, T5 says, "my principal put a lot of trust in me, I will not disappoint him" (first interview, June 2, 2018). T4 reflects on the school's professional development. She has moved schools before she comes here. She does not plan to leave as this school as it provides better PD opportunities; the PD is not monotonous (first interview, May 27, 2018). T3 discusses the colleagues that the colleagues in his department are resourceful (first interview, May 12, 2018).

Personal factors also play a significant role in sustaining commitment. All the out-of-field teachers have applied for teaching positions, so they do not take their opportunity for granted. All teachers express that they can make a difference by teaching, and this motivates them to improve in their daily job. T3 states that what he does here as a teacher comes out of his commitment, not the other way around. Because he is committed, he takes his role very seriously (first interview, May 12, 2018). For out-of-field teachers, commitment is not abstract. It is something shown through their daily practice. Their stories capture their deep commitment to succeed in their work and their role as a teacher.

This research provides evidence that the participants of this research choose to be out-of-field teachers to pursue their interest in teaching. They exemplify an initial commitment to teaching when they apply for the job and experience a challenge to their commitment after more than ten years in the job. A school plays an important role in sustaining teachers' commitment such as providing continuous support to teachers from their initial appointment when they are in service. Therefore, out-of-field teachers are equipped with necessary assistance before school begins and during their teaching. This support includes both provided and requested professional learning, being trusted and acknowledged by school leaders, and having resourceful colleagues. This research demonstrates that hiring out-offield teachers does not mean the school is creating wayward teachers, but it fosters professional growth. 
In this research, an out-of-field teacher's commitment is a motivation to pursue their interest in teaching originated as a pastime (teaching nephews, nieces, neighbors, and students in tuition centers). It is acceptable when there are schools that do not require teachers to hold qualifications. Their initial commitment leads to teaching and learning performance quality. Despite their commitment being challenged during their teaching, the teacher's desire to improve remains higher than the difficulties they face. This also leads to the teacher remaining in the profession for more than ten years.

This finding aligns with Leithwood, Harris, and Hopkins (2008). They suggest that administrative support is closely linked to a teacher's motivational skills, commitment, and working conditions they construct. When school leaders understand the consequences of hiring outof-field teachers and how to deploy human capital in their schools, the strategies for school improvement and the teaching, learning, and working situation can be conducive. By providing a series of ongoing professional development for out-of-field teachers, the schools improve teachers' competency and retain their teachers.

\section{CONCLUSIONS}

This research demonstrates that an out-of-field teacher's initial commitment to teach, learn, and grow coupled with school support, leads to professional growth. This research has implications for groups, including school leaders, out-of-field in-service teachers, and educational researchers. The research results can be used by school leaders to develop and enhance future professional learning opportunities for out-of-field teachers. It will show them how to teach effectively. It demonstrates how schools provide conducive learning environments for out-of-field in-service teachers to enhance their professional growth throughout the year. This research also addresses gaps in the literature relating to out-of-field teaching in Indonesia for educational researchers. It can inspire and support new initiatives for professional development.

The findings presented do have limitations, so they must be viewed cautiously. The research is limited to the discussion of out-of-field teachers' commitment to teach, learn, and grow. It is also limited by sample population and size. The generalizability of the findings is limited by the five teachers from established schools in Jakarta, Bandung, and Tangerang.

\section{ACKNOWLEDGEMENT}

The special gratitude is for all research participants: teachers and school leaders, who have selflessly given their valuable time for sharing their perspectives. Teachers' jobs are complex and starting teaching, as out-of-field novices add another layer of the complexity. It is privileged to learn from their individual experiences. Their contributions are invaluable to this research.

\section{REFERENCES}

Billett, S. (1993). What's in a setting? Learning in the workplace. Australian Journal of Adult and Community Education, 33(1), 4-14.

Billett, S. (2003). Workplace mentors: Demands and benefits. Journal of Workplace Learning, 15(3), 105-
113. https://doi.org/10.1108/13665620310468441.

Billett, S. (2004). Workplace participatory practices: Conceptualising workplaces as learning environments. Journal of Workplace Learning, 16(6), 312-324. https://doi. org/10.1108/13665620410550295.

Braun, V., \& Clarke, V. (2006). Using thematic analysis in psychology. Qualitative Research in Psychology, 3(2), 77-101. http://dx.doi. org/10.1191/1478088706qp063oa.

Creswell, J. W., \& Creswell, J. D. (2017). Research design: Qualitative, quantitative, and mixed methods approaches. California: SAGE publications.

Darling-Hammond, L. (2010). Recruiting and retaining teachers: Turning around the race to the bottom in high-need schools. Journal of Curriculum and Instruction, 4(1), 16-32. doi: 10.3776/joci.2010. v4n1p16-32.

Darling-Hammond, L., Berry, B. T., Haselkorn, D., \& Fideler, E. (1999). Teacher recruitment, selection, and induction: Policy influences on the supply and quality of teachers. In L. Darling-Hammond \& G. Sykes (Eds.), Teaching as the learning profession: Handbook of policy and practice (pp. 183-232). New Jersey: John Wiley \& Sons.

Day, C. (2008). Committed for life? Variations in teachers' work, lives and effectiveness. Journal of Educational Change, 9(3), 243-260. doi: 10.1007/s10833-0079054-6.

Day, C., Elliot, B., \& Kington, A. (2005). Reform, standards and teacher identity: Challenges of sustaining commitment. Teaching and Teacher Education, 21(5), 563-577. doi: 10.1016/j.tate.2005.03.001.

Day, C., \& Gu, Q. (2007). Variations in the conditions for teachers' professional learning and development: Sustaining commitment and effectiveness over a career. Oxford Review of Education, 33(4), 423-443. https://doi.org/10.1080/03054980701450746.

Du Plessis, A. E. (2013). Understanding the out-of-field teaching experience ( $\mathrm{PhD}$ thesis). Queensland: The University of Queensland.

Du Plessis, A. E. (2017). Out-of-field teaching practices: What educational leaders need to know. Berlin: Springer.

Du Plessis, A., Carroll, A., \& Gillies, R. M. (2015). Understanding the lived experiences of novice outof-field teachers in relation to school leadership practices. Asia-Pacific Journal of Teacher Education, 43(1), 4-21. https://doi.org/10.1080/135 9866X.2014.937393.

Eraut, M. (2014). Developing knowledge for qualified professionals. In O. Mcnamara, J. Murray, \& M. Jones (Eds.), Workplace learning in teacher education (pp. 47-72). Berlin: Springer.

Fransson, G., \& Frelin, A. (2016). Highly committed teachers: What makes them tick? A study of sustained commitment. Teachers and Teaching: Theory and Practice, 22(8), 896-912. https://doi.org/10.1080/1 3540602.2016.1201469.

Fuller, A., \& Unwin, L. (2004). Expansive learning environments: Integrating organizational and 
personal development. In A. Fuller (Ed.), Workplace learning in context (pp. 126-144). Abingdon: Routledge.

Hobbs, L. (2012). Teaching out-of-field: Factors shaping identities of secondary science and mathematics. Teaching Science: The Journal of the Australian Science Teachers Association, 58(1), 21-29.

Hobbs, L. (2013). Teaching 'out-of-field' as a boundarycrossing event: Factors shaping teacher identity. International Journal of Science and Mathematics Education, 11(2), 271-297. doi: 10.1007/s10763012-9333-4.

Huberman, M. (1989). The professional life cycle of teachers. Teachers College Record, 91(1), 31-57.

Ingersoll, R. M. (2005). The problem of underqualified teachers: A sociological perspective. Sociology of Education, 78(2), 175-178. doi: 10.1177/003804070507800206.

Ingersoll, R. (2006). Understanding supply and demand among mathematics and science teachers. Retrieved from https://repository.upenn.edu/gse_pubs/136.

Jakaria, Y. (2014). Analisis kelayakan dan kesesuaian antara latar belakang pendidikan guru sekolah dasar dengan mata pelajaran yang diampu. Jurnal Pendidikan dan Kebudayaan, 20(4), 499-514. doi: http://dx.doi. org/10.24832\%2Fjpnk.v20i4.162.

Jarvis-Selinger, S., Pratt, D. D., \& Collins, J. B. (2010). Journeys toward becoming a teacher: Charting the course of professional development. Teacher Education Quarterly, 37(2), 69-95.

Kim, E. G. (2011). Out-of-field secondary school teachers in Korea: Their realities and implications. KEDI Journal of Educational Policy, 8(1), 29-48.

Lampert, M., \& Ball, D. L. (1999). Aligning teacher education with contemporary K-12 reform visions. In L. Darling-Hammond \& G. Sykes (Eds.), Teaching as the learning profession: Handbook of policy and practice (pp. 33-53). New Jersey: John Wiley \& Sons.
Leithwood, K., Harris, A., \& Hopkins, D. (2008). Seven strong claims about successful school leadership. School Leadership and Management, 28(1), 27-42.

Robinson, V. (1985). Making do in the classroom: A report on the misassignment of teachers. Retrieved from https://eric.ed.gov/?id=ED263108.

Scribner, S. (1985). Knowledge at work. Anthropology \& Education Quarterly, 16(3), 199-206. https://doi. org/10.1525/aeq.1985.16.3.05x1486d.

Sharplin, E. D. (2014). Reconceptualising out-of-field teaching: Experiences of rural teachers in Western Australia. Educational Research, 56(1), 97-110. https://doi.org/10.1080/00131881.2013.874160.

Törner, G., \& Törner, A. (2012). Underqualified Math teachers or out-of-field-teaching in Mathematics-a neglectable field of action? In Mathematikunterricht im Kontext von Realität, Kultur und Lehrerprofessionalität (pp. 196-206). Vieweg+ Teubner Verlag.

Tsui, K. T., \& Cheng, Y. C. (1999). School organizational health and teacher commitment: A contingency study with multi-level analysis. Educational Research and Evaluation, 5(3), 249-268. https://doi.org/10.1076/ edre.5.3.249.3883.

Tyree Jr, A. K. (1996). Conceptualizing and measuring commitment to high school teaching. The Journal of Educational Research, 89(5), 295-304. https://doi. org/10.1080/00220671.1996.9941331.

Van Veen, K., Sleegers, P., \& Van de Ven, P. H. (2005). One teacher's identity, emotions, and commitment to change: A case study into the cognitive-affective processes of a secondary school teacher in the context of reforms. Teaching and Teacher Education, 21(8), 917-934. https://doi.org/10.1016/j.tate.2005.06.004. 